\title{
46. PRELIMINARY EXAMINATION OF THE OSTRACODES OF DSDP LEG 42B
}

\author{
R. H. Benson, Smithsonian Institution, Washington, D. C.
}

Eleven samples (1 from Hole 379A; 10 from Holes $380 / 380 \mathrm{~A}$ ) were sent to me for preliminary examination of the ostracodes. Numerous occurrences of ostracodes had been noted during shipboard examinations. These specimens were sent to R. Olteanu in Rumania, and more detailed studies of the ostracodes are being undertaken by G.F. Shchneyder and others in the USSR.

The ostracodes of the DSDP Black Sea cores are modern relics of late Miocene and Pliocene faunas whose species have changed little during the Pleistocene except in distribution. Many have wide geographic ranges over vast continental regions with close relatives known from throughout the Northern Hemisphere. Those Pleistocene species of the Soviet Union immediately north of the Black Sea have been described recently by Negadaev-Nikonov (1974); older faunas described from Bulgaria by Stancheva (1963, 1964, 1965). Faunas of Pannonian age connecting into the Mediterranean region were described by Pokorny from Czechoslovakia as early as 1952. Intermediate Paratethyan faunas from Yugoslavia have been described by Sokač (1972) and Krstić (1971).

Of the 11 samples examined, the ostracodes therein were disappointing in their variety, rarity, and poor preservation. There were no indications of relic Tethyan marine species which, if found, would have been of primary interest. Caspibrackish ostracodes from the shallow parts of the Sea of Azov are known to be among the most abundant ostracode faunas in the world (Caspers, 1957). Except for the allochthonous shells, they are extremely rare or absent in Recent cores from the deeper parts of the Black Sea. It is concluded, therefore, that the ostracodes in the 11 samples are not representative of the fauna as a whole. A more detailed study from other samples with more specimens and by ostracode workers with experience in faunas from outcrops around the edges of the Black Sea should be much more helpful.

\section{HOLE 379A}

One sample from Core 58, Section 4, 133-135 cm, contained 10 ostracode specimens; 6 of Cyprideis littoralis? and 4 of Candona sp. The fauna and position of these few specimens supports the suggestion that the Black Sea may have been near an alkaline-playa condition at the time of their burial. This combination of species and the absence of nektonic cypridopsine ostracodes is analogous to the alkaline-playa assemblages of the Pleistocene Lake Channing deposits of northern Texas (Benson, 1969). The lack of nodes on the Cyprideis instars suggests a high alkaline content (above $15 \%$ ). Candona is a benthic ostracode and known from deep fresh-water lakes (Lake Erie; Benson and MacDonald, 1963), thus that the permanence of the deeper basin water so-called "playa" cannot be estimated from this genus.

\section{HOLES 380/380A}

Of 10 samples examined from Cores $1,4,7,10,15$, and 32, ostracodes were found only in the late Quaternary Core 4 (four specimens of Hemicytheria folliculosa) and Core 15 (Cyprideis sp. instar). The specimens of Hemicytheria were blackened with sulfide, but without chitinous material. This would suggest that the waters were generally anoxic, but possibly shallower regions from which the shells could have drifted were meiomesohaline (salinity $3-8^{\circ} \% 0$ ). The concentration of four valves of this moderately uncommon species is curious and yet unexplainable with the material at hand. The presence of a single valve of Cyprideis in Core 15 means little as this is the most common species of the Black Sea. It could have come from higher salinities (mesohaline) as suggested in the shipboard report $(18 \%)$ because it has no nodes (highest range about $14 \%$ ).

The general absence or rarity of ostracodes in Leg 42B cores should be considered. Even though they are among the most abundant of the benthic microfossils in the cores (together with Ammonia becarii), they are nevertheless exceptionally rare by comparison to their modern distribution in the shallow parts of the Caspian Sea and the Black Sea. In cores of comparable age from the deepest parts of the Great Lakes of the United States and Canada (Lake Erie; Benson and MacDonald, 1963), major portions of the coarse sediment fraction are ostracode valves. The ostracode assemblages found in the upper parts of the Black Sea cores thus may not have lived in situ.

\section{GENERAL BIOSTRATIGRAPHY OF "CONTINENTAL" OSTRACODES}

If the faunal succession of non-marine ostracodes is understood anywhere, it is best done in the areas around and particularly to the north and east of the Black Sea. Local successions have been used for practical drilling needs and the ostracodes in the Paratethyan deposits are as common as some foraminifers in marine deposits. However, many problems remain in differentiating phenetic and genetic effects on carapace morphology, especially in deep water faunas. It seems obvious that although these first attempts to show any succession of Pleistocene events in the deep parts of the Black Sea may lack detail, the potential for showing overall trends is there. In the study of deep water faunas, sudden morphological or 
assemblage shifts are found to have been rare or to be the result of local effects. Temperature changes, such as would be associated with glacial-interglacial stages, do not have more influence on evolution of ostracodes than does seasonal variation, whereas shifts in salinity or alkalinity or depth have decided influence. If there have been any long-term effects on ostracode evolution that would have stratigraphic successional value, they will probably only become apparent when a morphologic series is established; this is yet to be done.

\section{REFERENCES}

Benson, R.H., 1969. Ostracodes of the Rita Blanca Lake deposits. Geol. Soc. Am. Mem., v. 113, p. 107-115.

Benson, R.H. and MacDonald, H.C., 1963. Postglacial (Holocene) ostracodes from Lake Erie: University of Kansas Paleontol. Contrib., Arthropoda, v. 4, p. 1-26.

Caspers, H., 1957. Black Sea and Sea of Azov: Geol. Soc. Am. Mem. 67, v. 1, p. 801-890.

Krstić, N., 1971. Ostracode biofacies in the Pannone. In Oertli, H.J., (Ed.), Paleoecologie d'Ostracodes, Pau, 1970: Bull. Centre Recherches Pau-SNPA, v. 5, p. 391397.

Negadaev-Nikonov, K.N., 1974. Ostracodes of the Continental Pleistocene of the Southern European part of the U.S.S.R.: Acad. Nauk Moldavia, SSSR, Paleontology and Biostratigraphy.
Pokorny, V., 1952. The ostracodes of the so-called basal horizon of the Subglobosa beds at Hodonin (Pliocene, Inner Alpine Basin Czechoslovakia): Sbornik Ustredniho Ustavu Geologickelho 19.

, 1955. Contribution to the morphology and taxonomy of the Subfamily Hemicytherinae Puri: Acta Univ. Carolinae, Geologica.

Sokač, A. 1972. Pannonian and Pontian ostracode fauna of Mt. Medvednica: Paleontologia Yugoslavia, v. 11, p. 1140.

Stancheva, M., 1962. Ostracoda from the Neogene in Northwestern Bulgaria, I. Tortonian Ostracoda. Travaux sur la Geologie de Bulgarie: Paleontologie, v. 4, p. 5-75.

1963. Ostracoda from the Neogene in Northwestern Bulgaria, II. Sarmation Ostracoda. Travaux sur la Geologie de Bulgarie: Paleontologie, v. 5, p. 5-73.

, 1964. Ostracoda from the Neogene in Northwestern Bulgaria, III. Maeotian Ostracoda. Travaux sur la Geologie de Bulgarie: Paleontologie, v. 6, p. 55-115. 1965. Ostracoda from the Neogene in Northwestern Bulgaria, Travaux sur la Geologie de Bulgarie: Paleontologie, v. 7, p. 15-69.

\section{ACKNOWLEDGMENTS}

The author expresses thanks to Ramil Wright, Maria B. Cita, Joseph E. Hazel, and Henri J. Oertli for their reviews of this report. Giles Carbonnel and Germain Bizon were also sent copies of the manuscript. This research was funded by the Smithsonian Institution. 